\title{
MENTAL HEALTH IN EARLY ADULTHOOD: PREDICTIVE ROLE OF GROWTH AND SELF-PROTECTION VALUES
}

\author{
Agnieszka Franczok-Kuczmowska, MA \\ Department of Management and Social Communication, \\ Institute of Applied Psychology, Jagiellonian University, Poland
}

\begin{abstract}
Early adulthood is a developmental stage during which several mental health issues are noted. The same time in the context of multiple life options offered by the modern world and no clear evaluation criteria, early adults value hierarchy is especially valuable area of research. In the light of research on association between values and subjective well-being, the relationship between values and mental health still needs to be established. The aim of the study was to transfer Schwartz value theory to health psychology area and verify whether Growth values and Self-Protection values correlate with and predict mental health in depression, anxiety and resilience in polish population of early adults. Participants completed Portrait Value Questionnaire PVQ40, General Health Questionnaire GHQ-12 and Brief Resilience Scale BRS. The univariate and multivariate linear regression were employed in order to verify hypothesis. Results indicate that the Growth values and the Self-Protection values predict mental health in early adulthood. Conformity increases depression and decreases resilience, Self-Direction decreases depression and increases resilience, Tradition increases depression, while Achievement and Stimulation increase resilience. In the light of given results, Self-Direction and Conformity presents the greatest relation to mental health in both positive and negative aspects. Discussion, study limitations, and suggestions for further research were stated.
\end{abstract}

Key words: values, mental health, depression, anxiety, resilience

\section{INTRODUCTION}

Mental health in early adulthood remains an area to be more extensively investigated. High prevalence of depression and anxiety (e.g. Oleś, 2011) as well as well great amount of negative emotionality and high self-harm activities (Gurba, 2011, Patel, Flisher, Hetrick \& McGorry, 2007) are reported, though research remains limited. Early adulthood is a period in life between 18/20 and 30/25 years of age (Oleś, 2011) and it is a time of new challenges, new individual and social roles and activities, including choosing a partner and building stable relationships, managing a home or establishing one's career (Gurba, 2008; Hutteman, Hennecke, Orth, Reitz \& Specht, 2014). Modern socio-cultural changes have moved adults roles in time, as a consequence resulting in a delay in age of marriage formation and children upbringing 
(Brzezińska, Kaczan, Piotrowski \& Rękosiewicz, 2011). As nowadays many life options and opportunities are possible, the same time there are no clear evaluation criteria established (Oleś, 2011), it may result in many early adults life difficulties. Thus value hierarchy in early adulthood is especially interesting area of research.

Value area is being nowadays explored and described, though one theory seems to summarize most of values characteristics and thus it is widely used and researched. Schwartz theory of basic human values (e.g. Schwartz, 1992; Schwartz 2012) distinguishes ten cross-cultural, universal values that form a curricular motivational continuum (Cieciuch \& Schwartz, 2012). Schwartz theory assumes that values are concepts or beliefs which refer to desirable goals: end states or behaviors, moreover they transcend specific actions and situation as well as guide selection or evaluation of behavior and event; last but not least, they are ordered by relative importance (Cieciuch et al., 2012, Schwartz, 2003).

Conformity, Tradition, Benevolence, Universalism, Self-direction, Stimulation, Hedonism, Achievement, Power and Security lie in a circle and are organized by motivational background (Cieciuch, Davidov, Vecchione, Beierlein \& Schwartz, 2017). Value position in the circle is determined by two rules: compatibility and conflict. The more compatible are motivational goal of the values, the closer they are placed, for example Conformity and Security. Consequently, the more oppositional or conflicted are motivational goals, the further values are placed, for example Security and Stimulation (Doring, Schwartz, Cieicuch, Groene, Glatzel, Hrasimczuk, Janowicz, Nyagolova, Scheefer, Allritz, Milfont \& Bilsky, 2015). SelfTranscendence (Universalism and Benevolence) versus Self-

Enhancement (Achievement and Power) as well as Openness to Change (Hedonism, Stimulation and Self-Direction) versus Conservation (Security, Conformity and Tradition) create two bipolar, higher order dimensions based on the relation among the ten values (Schwartz \& Sortheix, 2018). Moreover, values aimed at Personal Focus (Self-Enhancement and Openness to Change) and aimed at Social Focus (Conservation and Self-Transcendence) create even more general division. And finally, the last division refers to healthy and unhealthy values: Growth values that are anxiety-free and lead to self-expansion and self-actualization (Benevolence, Universalism, Self-Direction, Stimulation, Hedonism, partially Achievement) and Self-Protection values that are aimed at anxiety-avoidance and are cognitive transformation of deficiency needs (Tradition, Conformity, Security, Power) (Schwartz et al., 2018).

In the light of many research on association between values and subjective well-being (Schwartz et al., 2018), Benevolence, Stimulation and Self-Direction, as well as Hedonism and Universalism relate positively to subjective well-being while Conformity relates negatively to subjective well-being. World Health Organization defines mental health as a "state of well-being in which every individual realizes his or her own potential, can cope with the normal stresses of life, can work productively and fruitfully, and is able to make a contribution to her or his community" (WHO, 2014). What is more, mental health is something more than just lack of pathology it's added value to one's life. Based on that, as subjective well-being is an integrative part of mental health, it provides a bridge to association between values and mental health. 
Resilience as an ability to "bounce back or recover from stress, to adapt to stressful circumstances, to not become ill despite significant adversity, and to function above the norm in spite of stress or adversity" (Smith, Dalen, Wiggins, Tooley, Christopher \& Bernard, 2008) or as a process of effective overcoming negative life events and bouncing back after stressful time (Borucka, 2011; Borucka \& Ostraszewski, 2012; Masten \& Powell, 2003; Ogińska-Bulik, 2011; Junik, 2011; Luthar 1991; Luthar, Cicchetti \& Becker, 2000; Wright, Masten \& Narayan, 2013; Venter \& Snyders, 2009) remains important factor in mental health area. As $\mathrm{Hu}$, Zhang and Wang (2014) reported, the resilience correlates negatively to negative indicators of mental health and correlates positively to positive indicators of mental health. Thus, resilience performs protective role for mental health.

\section{RESEARCH GOALS AND OBJECTIVES}

The aim of the study is to transfer Schwartz value theory to health psychology area. As the foregoing research have distinguished Growth values and Self-Protection values, the article objective is to answer the questions whether Growth and SelfProtection values correlate with and predict early adults mental health in depression and anxiety symptoms as well as whether Growth and Self-Protection values correlate with and predict early adults resilience. In order to verify those questions, following research hypotheses were stated:

1. Values relate to mental health: Self-Protection values correlate positively and predict depression and anxiety symptoms while Growth values correlate negatively and predict depression and anxiety symptoms.

2. Values relate to resilience: Self-Protection values correlate negatively and predict resilience while Growth values correlate positively and predict resilience.

\section{METHODS}

Participants. Current research consists of 112 participants in early adulthood $(M=25,7, S E=.5)$. Research was conducted in Poland and consists of polish population. Out of recruited respondents $46,4 \%$ were men and $53,5 \%$ were women. $78 \%$ of participants inhabited big cities and $22 \%$ inhabited medium and smaller cities. $68 \%$ of respondents felt moderate financial stability, $14 \%$ felt great financial stability and $18 \%$ felt lack of financial stability. $77 \%$ obtained diploma of higher education. Informed consent has been appropriately obtained.

Measures. Each participant fully completed set of research questionnaires. The set consists of socio-demographic questionnaire, Portrait Value Questionnaire PVQ-40 by Schwartz (2001) in polish adaptation by Cieciuch and Zalewski (2011), General Health Questionnaire GHQ-12 by David Goldberg in polish adaptation by Makowska and Merecz (2001) and Brief Resilience Scale BRS by Smith, Dalen, Wiggins, Tooley, Christopher and Bernard (2008) in polish adaptation by FranczokKuczmowska. The Portrait Value Questionnaire PVQ-40. The scale is used in order to measure 10-value construct of cross-cultural Schwartz's value theory: Universalism, Benevolence, Conformity, Tradition, Security, Power, Achievement, 


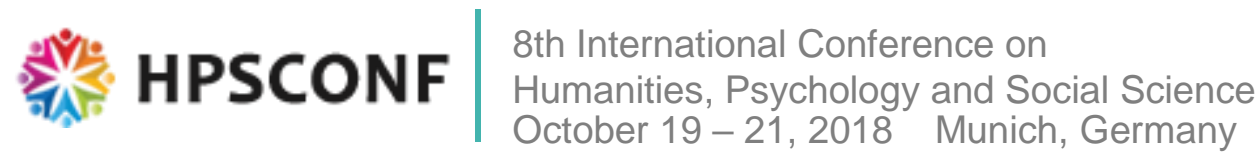

Hedonism, Stimulation and Self-Direction. Participants respond to each of 40 items describing different people's goal, aspirations or wishes that refer to measured values. Cronbach's $\alpha$ reaches above 0.80 and presents good relevance. The General Health Questionnaire GHQ-12. The scale is used in order to assess mental health in Depression and Anxiety symptoms. Participants respond to each of 12 items. Cronbach's $\alpha$ reaches above 0.80. questionnaire presents good relevance. The Brief Resilience Scale BRS. The scale measures Resilience as ability to bounce back or recover from stress. Participants respond to each of 6 items. Cronbach's $\alpha$ reaches above 0.80 .

\section{RESULTS}

In order to meet research objectives IBM SPSS Statistics software was used in data analysis. Descriptive statistics are presented in Table 1. Univariate linear regression analyses are presented in Table 2 and Table 3.

Table 1

Descriptive statistics: mean, standard deviation, minimum and maximum of factors.

\begin{tabular}{|c|c|c|c|c|c|c|c|c|c|c|c|c|}
\hline & 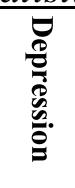 & 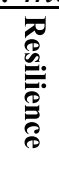 & 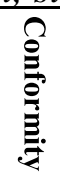 & 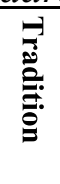 & 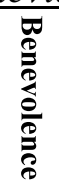 & 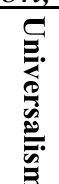 & 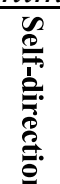 & 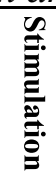 & 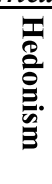 & & & Pe \\
\hline
\end{tabular}

\begin{tabular}{rccccccccccccc}
\hline $\boldsymbol{M}$ & 8.53 & 4.45 & 3.08 & 3.60 & 3.14 & 4.59 & 4.46 & 4.75 & 3.83 & 3.72 & 4.30 & 3.13 & 3.88 \\
$\boldsymbol{S D}$ & 3.65 & 2.85 & .86 & 1.00 & 1.02 & .83 & .86 & .92 & 1.22 & 1.21 & 1.08 & 1.16 & .89 \\
Min & 1.00 & .00 & 1.00 & 1.25 & .50 & 2.50 & 2.00 & 1.75 & 1.33 & .67 & 1.50 & 1.00 & 1.00 \\
Max & 20.00 & 15.00 & 5.00 & 5.75 & 5.75 & 6.00 & 6.00 & 6.00 & 6.00 & 6.00 & 6.00 & 5.67 & 5.60 \\
\hline
\end{tabular}

Table 2

Linear regression: Schwartz 10-value construct and mental health: Depression and Anxiety symptoms.

\begin{tabular}{rccccccc}
\hline \multicolumn{7}{c}{ DEPRESSION } \\
\hline Models & $r$ & $R^{2}$ & Adj.. $R^{2}$ & $F(d f=1,110)$ & $B(\mathrm{SE})$ & $\beta$ & $t$ \\
\hline Conformity & $.21^{*}$ & .04 & .035 & $5.023^{*}$ & $.597(.266)$ & .209 & $2.241^{*}$ \\
Tradition & $.23^{*}$ & .05 & .042 & $5.910^{*}$ & $.63(.259)$ & .226 & $2.431^{*}$ \\
Security & .06 & .00 & -.005 & .395 & $.192(.306)$ & .060 & .628 \\
Power & -.02 & .00 & -.009 & .055 & $-.055(.235)$ & -.022 & -.235 \\
Achievement & -.02 & .00 & -.009 & .038 & $-.0489(.251)$ & -.019 & -.195 \\
Hedonism & -.10 & .01 & .001 & 1.077 & $-.232(.224)$ & -.098 & -1.038 \\
Stimulation & -.05 & .00 & -.006 & .321 & $-.126(.222)$ & -.054 & -.566 \\
Self-direction & $-.21^{*}$ & .04 & .035 & $5.072^{*}$ & $-.652(.289)$ & -.210 & $-2.252^{*}$ \\
Universalism & -.16 & .03 & .016 & 2.838 & $-.524(.311)$ & -.159 & -1.685
\end{tabular}




\section{HPSCONF}

8th International Conference on

Humanities, Psychology and Social Science

October 19-21, 2018 Munich, Germany

\begin{tabular}{|c|c|c|c|c|c|c|c|}
\hline Benevolence & .00 & .00 & -.009 & .000 & $-.002(\mathrm{G} 13)$ & -.001 & -.007 \\
\hline & \multicolumn{7}{|c|}{ ANXIETY } \\
\hline Models & $r$ & $R^{2}$ & Adj. $R^{2}$ & $F(d f=1,110)$ & $B(\mathrm{SE})$ & $\beta$ & $t$ \\
\hline & \multicolumn{6}{|c|}{ Conformity } & \\
\hline .14 & .02 & .009 & 2.061 & $.496(.345)$ & .136 & 1.436 & \\
\hline Tradition & .04 & .00 & -.007 & .191 & $.149(.340)$ & .042 & .437 \\
\hline Security & -.05 & .00 & -.007 & .281 & $-.208(.392)$ & -.050 & -.530 \\
\hline Power & .03 & .00 & -.008 & .127 & $.107(.300)$ & .034 & .357 \\
\hline Achievement & .02 & .00 & -.009 & .054 & $.075(.322)$ & .022 & .233 \\
\hline Hedonism & .06 & .00 & -.005 & .457 & $.194(.287)$ & .064 & .676 \\
\hline Stimulation & .11 & .01 & .003 & 1.309 & $.324(.283)$ & .108 & 1.144 \\
\hline Self-direction & -.02 & .00 & -.009 & .051 & $-.085(.379)$ & -.022 & -.226 \\
\hline Universalism & .05 & .00 & -.006 & .325 & $.230(.403)$ & .054 & .570 \\
\hline Benevolence & .08 & .01 & -.003 & .674 & $.343(.418)$ & .078 & .821 \\
\hline
\end{tabular}

Note: ${ }^{*} \mathrm{p} \leq .05$.

Table 2

Linear regression: Schwartz 10-value construct and Resilience.

RESILIENCE

\begin{tabular}{|c|c|c|c|c|c|c|c|c|}
\hline & Models & $r$ & $R^{2}$ & $F(d f=1,110)$ & $B(\mathrm{SE})$ & & $\beta$ & $t$ \\
\hline Conformity & $-.24 * *$ & .06 & .048 & $6.600 * *$ & $-.204(.079)$ & -.238 & $-2.569 * *$ & \\
\hline Tradition & -.13 & .02 & .009 & 2.026 & $-.113(.079)$ & -.134 & -1.424 & \\
\hline Security & .05 & .00 & -.007 & .244 & $.045(.092)$ & .047 & .494 & \\
\hline Power & .16 & .02 & .016 & 2.757 & $.116(.070)$ & .156 & 1.661 & \\
\hline Achievement & $.24 * *$ & .06 & .048 & $6.609 * *$ & $.188(.073)$ & .238 & $2.571 * *$ & \\
\hline Hedonism & .03 & .00 & -.008 & .127 & $.024(.067)$ & .034 & .356 & \\
\hline Stimulation & $.22 *$ & .05 & .038 & $5.329^{*}$ & $.150(.065)$ & .215 & $2.309^{*}$ & \\
\hline Self-direction & $.25^{* *}$ & .06 & .055 & $7.477 * *$ & $.235(.086)$ & .252 & $2.734 * *$ & \\
\hline Universalism & -.01 & .00 & -.009 & .962 & $-.004(.095)$ & -.005 & -.047 & \\
\hline Benevolence & .07 & .00 & -.005 & .478 & $.068(.098)$ & .066 & .692 & \\
\hline
\end{tabular}

Note: $* \mathrm{p} \leq .05 ; * * \mathrm{p} \leq .01$.

Several univariate linear regression models were examined to predict

Depression, Anxiety and Resilience level based on ten individual values: Conformity, Tradition, Security, Power, Achievement, Hedonism, Stimulation, Self-Direction, Universalism and Benevolence.

Depression. The results of univariate regression indicate that three values predict individually Depression: Conformity $(F(1,110)=5.023, p<.05, \beta=.209)$, Tradition $(F(1,110)=5.91 . p<.05, \beta=.226)$ and Self-Direction $(F(1,110)=5.072, p$ $<.05, \beta=-.210)$. Predictive Power of individual values remains weak as Conformity predicts $4 \%$, Tradition predicts $5 \%$ and Self-Direction predicts $4 \%$ of Depression. The higher Conformity and Tradition, the higher Depression level. Conversely, the higher Self-Direction, the lower Depression level. In multivariate linear regression 
$(F(1,110)=4.23 . p<.01, \mathrm{R}=.32)$ Conformity $(\beta=.114, p>.05)$, Tradition $(\beta=$ $.172, p>.05)$, and Self-Direction $(\beta=-.203, p<.05)$, predict $10.5 \%$ of

Depression. Given results indicate that out of personal values Self-Direction predicts Depression to the greatest extent. The same time Self-Direction seems to perform potential protective factor function. Security, Power, Achievement, Hedonism, Stimulation, Universalism and Benevolence do not significantly predict Depression.

Anxiety. The results of univariate regression indicate that none of the values: Conformity, Tradition, Security, Power, Achievement, Hedonism, Stimulation, SelfDirection, Universalism, Benevolence predict Anxiety level.

Resilience. The results of univariate regression indicate that four values predict individually Resilience: Conformity $(F(1,110)=6.600, p<.01, \beta=-.238)$, Achievement $(F(1,110)=6.609, p<.01, \beta=.238)$, Stimulation $(F(1,110)=5.329, p$ $<.05, \beta=.215)$ and Self-Direction $(F(1,110)=7.477, p<.01, \beta=.252)$. Predictive Power of these individual values remains weak as each: Conformity, Achievement and Self-Direction predicts $6 \%$ while Stimulation predicts 5\% of Resilience. The higher Conformity, the lower Resilience. Conversely, the higher Achievement, Stimulation and Self-Direction, the higher Resilience. In multivariate linear regression $(F(4,107)=5.048, p \leq .001, \mathrm{R}=.40)$ Conformity $(\beta=-.264, p<.01)$, Achievement $(\beta=.227, p<.05)$, Self-Direction $(\beta=.156, p>.05)$ and Stimulation $(\beta=.012, p>$ $.05)$ predict $16 \%$ of Resilience. Given results indicate that out of personal values Conformity and Achievement predict Resilience to the greatest extent. The same time Conformity seems to perform potential risk factor function and Achievement seems to perform protective factor function. Tradition, Security, Power, Hedonism, Universalism and Benevolence do not significantly predict Resilience.

\section{DISCUSSION AND CONCLUSIONS}

The aim of the study was to transfer Schwartz value theory to health psychology area and to answer the questions whether Growth and Self-Protection factors correlate with and predict early adults mental health in depression and anxiety symptoms as well as whether Growth and Self-Protection values correlate with and predict early adults resilience.

Presented results indicate that the higher level of individually measured SelfProtection values: Conformity and Tradition, the greater is depression level in early adults. The same time the higher Growth value: Self-Direction, the lower is depression level. Thus hypothesis has been confirmed. Self-Direction performs the greatest predictive role on Depression out of significant values. Given results are consistent with recent findings regarding positive influence of internal locus of control, self-agency (Czabała \& Kluczyńska, 2015) or coherence as manageability (Antonovsky, 2005) on mental health. Moreover, people with external locus of control conform more (Spector, 1983), while people with internal locus of control perform better results in mental health (Shojaee \& French, 2015). On the other hand, early adulthood is a time of taking new challenges and new social roles in context of which Self-Direction perform a developmentally desirable role. In fact, one of the task of early adulthood is to fully autonomize and in a result Self-Direction should enable healthy development. 
Results indicate that the higher individually measured Growth values: SelfDirection, Achievement and Stimulation, the greater is resilience level. The same time the higher Self-Protection value: Conformity, the lower is resilience in early adults. Thus hypothesis has been confirmed. Given results are consistent with previous findings on Self-Direction as a predictor of resilience (Maercker, Zhang, Gao, Kochetkov, Lu, Sang, Yang, Schneider \& Margraf, 2015). Out of significant values, Conformity seems to perform potential risk factor function and Achievement seems to perform the greatest protective factor function.

In current research, Growth values do not relate to anxiety symptoms in early adults, which confirms theoretical assumption. On the other hand, Self-Protective values do not predict anxiety, surprisingly. It stands in opposition to the theory regarding anxiety-avoidance motivational background of them. Possible explanation may lie in the construct on anxiety. As General Health Questionnaire is a screening tool for psychiatric disorders (Kim, Cho, Park, Hong, Sohn, Bae, Jeon, Chang, Lee \& Park, 2015) and measures anxiety in clinical understanding, anxiety background in the Schwartz theory may be more latent and may require more adjusted or more sophisticated instrument. This hypothesis is supported by results: Conformity, even though not significant, performs the greatest correlation to anxiety out of the ten values as anticipated. In the light of given results, Self-Direction and Conformity presents the greatest relation to mental health in both positive (resilience) and negative (depression) aspects. Thus future research regarding Self-Direction and Conformity influence on mental health is strongly recommended.

To sum up, presented results indicate that Self-Protection and Growth values correlate with and predict mental health in depresssion symptoms and resilience. Still the relationship remains weak. Current research is not free of limitations. Firstly, the study was planned in correlational and cross-sectional design, which provide poor explanatory power. Secondly, study implemented self-description instruments that provide subjective perspective and is lacking of objective one. Thirdly, study was restricted to one cohort - early adults in polish society and as a consequence generalization possibility is limited. Moreover, study population has limited number. Therefore some suggestions are concluded so as to provide more reliable and solid conclusion.

As in presented results the value-mental health relationship power is weak, major objective is to answer the question whether there are any conditions in which the relationship may be stronger or does not occur at all. Firstly, there is a strong suggestion for experimental design as values manipulation (e.g. different priming procedures are already described) which will control for disturbing factors and make relationship clear. Another suggestion is longitudinal design that allows to observe the relationships as a dynamic process. Furthermore, greatest participants number is suggested as well as international or even cultural comparison is recommended. Next, early adulthood is complex developmental period in which occur many differences in social roles and responsibility in the beginning and in the last stage of the phase, thus inter-phase differentiation may be implemented. It may be also valuable to compare early adulthood and middle adulthood in the value-mental health relationship. Additionally, instrument chosen to measure anxiety can be replaced with more sensitive tool aimed at non-clinical anxiety construct. Last but not least, resiliency has 
many definition and the one chosen for the article is only one way of understanding. It would be valuable to check how does values-resilience relationship work in wider resilience definition.

\section{ACKNOWLEDGEMENT}

Praca finansowana ze środków na badania naukowe lub prace rozwojowe oraz zadania z nimi związane służące rozwojowi młodych naukowców oraz uczestników studiów doktoranckich.

\section{REFERENCES}

Antonovsky, A. (2005). Rozwikłanie tajemnicy zdrowia: Jak radzić sobie ze stresem $i$ nie zachorować. Instytut Psychiatrii i Neurologii.

Borucka, A. (2011). Koncepcja resiliency. Podstawowe założenia i nurty badań [The concept of resiliency: Basic research tenets and tendencies]. Resiliency. Teoria-badania-praktyka [Resiliency: Theory, reserach, practice], 11-28.

Borucka, A., \& Ostaszewski, K. (2012). Czynniki i procesy resiliency wśród dzieci krzywdzonych. Dziecko Krzywdzone. Teoria, badania, praktyka, 11(3), 7-26.

Brzezińska, A. I., Kaczan, R., Piotrowski, K., Rękosiewicz, M. (2011). Odroczona dorosłość: fakt czy artefakt? Nauka 4, 67-107.

Cieciuch, J., \& Schwartz, S. H. (2012). The number of distinct basic values and their structure assessed by PVQ-40. Journal of personality assessment, 94(3), 321328.

Cieciuch, J., Davidov, E., Vecchione, M., Beierlein, C., \& Schwartz, S. H. (2014). The cross-national invariance properties of a new scale to measure 19 basic human values: A test across eight countries. Journal of Cross-Cultural Psychology, 45(5), 764-776.

Czabała, J. C., \& Kluczyńska, S. (Eds.). (2015). Poradnictwo psychologiczne. Wydawnictwo Naukowe PWN.

Döring, A. K., Schwartz, S. H., Cieciuch, J., Groenen, P. J., Glatzel, V., Harasimczuk, J. Janowicz, N., Nyagolova, M., Scheefer, E. R., Allritz, M., Milfont, T. L. \& Bilsky W. (2015). Cross- cultural evidence of value structures and priorities in childhood. British Journal of Psychology, 106(4), 675-699.

Gurba, E. (2011). Wczesna dorosłość. W: J. Trempała (red.), Psychologia rozwoju człowieka. Podręcznik akademicki (s. 287-311). Warszawa: PWN.

$\mathrm{Hu}, \mathrm{T}$., Zhang, D., \& Wang, J. (2015). A meta-analysis of the trait resiliency and mental health. Personality and Individual Differences, 76, 18-27.

Hutteman, R., Hennecke, M., Orth, U., Reitz, A. K., \& Specht, J. (2014). Developmental tasks as a framework to study personality development in adulthood and old age. European Journal of Personality, 28(3), 267-278.

Junik, W. (2011). Resilience. Teoria - badania-praktyka. Warszawa: Wydawnictwo Edukacyjne Paramedia.

Kim, Y. J., Cho, M. J., Park, S., Hong, J. P., Sohn, J. H., Bae, J. N., ... Park, J.-I. (2013). The 12-Item General Health Questionnaire as an Effective Mental 
Health Screening Tool for General Korean Adult Population. Psychiatry Investigation, 10(4), 352-358. http://doi.org/10.4306/pi.2013.10.4.352

Luthar, S. S. (1991). Vulnerability and resiliency: A study of high-risk adolescents. Child development, 62(3), 600.

Luthar, S. S., Cicchetti, D. \& Becker, B. (2000). The construct of resiliency: A critical evaluation and guidelines for future work. Child development, 71(3), 543-562.

Masten, A. \& Powell, J. 2003. A resiliency framework for research, policy, and practice. In: S. Luther (red.). Resiliency and vulnerability: Adaptation in the context of childhood adversities. Cambridge: Cambridge University Press. Maercker, A., Zhang, X. C., Gao, Z., Kochetkov, Y., Lu, S., Sang, Z., Yang, S., Schneider, S. \& Margraf, J. (2015). Personal value orientations as mediated predictors of mental health: A three-culture study of Chinese, Russian, and

German university students. International Journal of Clinical and Health Psychology, 15(1), 8-17.Ogińska-Bulik, N. (2011). Rola prężności psychicznej w przystosowaniu się kobiet do choroby nowotworowej. Psychoonkologia, 1, 16-24.

Oleś, K. P. (2011). Psychologia człowieka dorosłego. Ciągłość - zmiana - integracja. Warszawa: Wydawnictwo Naukowe PWN.

Schwartz, S. H. (1992). Universals in the content and structure of values: Theoretical advances and empirical tests in 20 countries. In Advances in experimental social psychology (Vol. 25, pp. 1-65). Academic Press.

Schwartz, S. H. (2003). A proposal for measuring value orientations across nations. Questionnaire Package of the European Social Survey, 259-290

Schwartz, S. H. (2012). An overview of the Schwartz theory of basic values. Online readings in Psychology and Culture, 2(1), 11.

Schwartz, S. H., \& Sortheix, F. (2018). Values and Subjective Well-Being. In E. Diener, S. Oishi, \& L. Tay (Eds.), Handbook of Well-Being (pp. 1-25). Salt Lake City, UT: Noba Scholar. Retrieved from http://www.nobascholar.com/chapters/51

Shojaee, M., \& French, C. (2014). The Relationship between Mental Health Components and Locus of Control in Youth. Psychology, 5, 966-978.

Spector, P. E. (1983). Locus of control and social influence susceptibility: Are externals normative or informational conformers?. The Journal of Psychology: Interdisciplinary and Applied.

World Health Organization (2014). Mental Health: a State of Well-being. Downloaded from: http://www.who.int/features/factfiles/mental_health/en/

Wright, M. O., D., Masten, A. S., Narayan, A. J. (2013). Resiliency processes in development: four waves of research on positive adaptation in the context of adversity. In: S. Goldstein, R.B. Brooks (red.), Handbook of Resiliency in Children (s. 15-37). Nowy Jork: Springer. 